\title{
EFEKTIFITAS ANTISEPTIK GEL HAND SANITIZER EKSTRAK ETANOL PELEPAH PISANG KEPOK (Musa paradisiaca L.) TERHADAP BAKTERI Staphylococcus aureus DAN Escherichia coli
}

\author{
(ANTISEPTIC EFFECTIVENESS OF HAND SANITIZER GEL OF \\ KEPOK BANANA FRUIT (Musa paradisiaca L.) ETHANOL EXTRACT AGAINST \\ Staphylococcus aureus AND Escherichia coli)
}

\author{
HOLIFAH $^{1}$, YANI AMBARI $^{1}$, ARISTA WAHYU NINGSIH ${ }^{1}$, BUTET SINAGA $^{1}$, \\ IIF HANIFA NURROSYIDAH ${ }^{2}$ \\ ${ }^{1}$ Program Studi S1 Farmasi, STIKES RS Anwar Medika, Jl. By Pass Krian, KM 33, Balongbendo, Sidoarjo \\ ${ }^{2}$ Program Studi DIII Farmasi, STIKES RS Anwar Medika, Jl. By Pass Krian, KM 33, Balongbendo, Sidoarjo
}

\begin{abstract}
Abstrak: Hand sanitizer merupakan salah satu bahan antiseptik berupa gel yang sering digunakan masyarakat sebagai media pencuci tangan yang praktis. Penggunaan hand sanitizer lebih efektif dan efisien bila dibanding dengan menggunakan sabun dan air sehingga masyarakat banyak yang tertarik menggunakannya. Berdasarkan Priosoeryanto, dkk (2006) pelepah pisang kepok mempunyai efek sebagai antibakteri karena mempunyai senyawa saponin, tanin, dan flavonoid, penelitian ini bertujuan untuk mengetahui efektivitas antiseptik gel hand sanitizer ekstrak etanol pelepah pisang kepok (Musa paradisiaca L.) terhadap bakteri Staphylococcus aureus dan Escherichia coli. Ekstrak yang digunakan yaitu dengan konsentrasi 35\%, 40\%, dan 45\%. Pelepah pisang kepok memiliki kandungan senyawa saponin, tannin, terpenoid, flavonoid, dan alkaloid sehingga dapat digunakan sebagai antibakteri setelah diformulasikan menjadi gel hand sanitizer kemudian diuji efektifitas pada bakteri Staphylococcus aureus dan didapatkan hasil zona hambat pada formulasi 1 (35\%) yaitu 0,6453 $\mathrm{mm}$, pada formulasi $2(40 \%)$ yaitu $1,979 \mathrm{~mm}$, dan pada formulasi $3(45 \%)$ yaitu $2,583 \mathrm{~mm}$. Hasil zona hambat bakteri Escherichia coli pada formulasi $1(35 \%)$ yaitu $0 \mathrm{~mm}$, pada formulasi $2(40 \%)$ yaitu $0 \mathrm{~mm}$, dan pada formulasi $3(45 \%)$ didapatkan hasil yaitu $1,875 \mathrm{~mm}$. Berdasarkan zona hambat yang dihasilkan maka gel hand sanitizer ekstrak etanol pelepah pisang kepok (Musa paradisiaca L.) pada konsentrasi 35\%, 40\%, dan 45\% tidak efektif sebagai antibakteri Staphylococcus aureus dan Escherichia coli karena zona hambat yang dihasilkan sangat lemah (kurang dari $5 \mathrm{~mm}$ ).
\end{abstract}

Kata kunci: Antibakteri, Escherichia coli, Hand sanitizer, Musa paradisiaca L., Staphylococcus aureus

\begin{abstract}
Hand sanitizer is an antiseptic ingredient in the form of a gel that is often used by the public as a practical hand washing medium. The use of hand sanitizers is more effective and efficient than using soap and water so that many people are interested in using it. Based on Priosoeryanto, dkk (2006) Kepok banana stalk has an antibacterial effect because it has saponins, tannins, and flavonoids compounds, this study aims to determine the effectiveness of the antiseptic gel hand sanitizer ethanol extract of Kepok banana stalk (Musa paradisiaca L.) against Staphylococcus aureus and Escherichia coli bacteria. The extracts used were 35\%, 40\%, and $45 \%$ concentrations. Kepok banana leaves contain saponins, tannins, terpenoids, flavonoids, and alkaloids so that they can be used as antibacterial agents after being formulated and then tested for the effectiveness of Staphylococcus aureus bacteria, which results in formulation $135 \%$, namely $0.6453 \mathrm{~mm}$, in formulation 2 $40 \%$, namely 1.979 , and in formulation $345 \%$ is 2.583 . Whereas for Escherichia coli the results obtained in formulation 1 were $35 \%$, namely 0 , in formulation $240 \%$, namely 0 , and in formulation $345 \%$ the results were $1.875 \mathrm{~mm}$. Gel hand sanitizer ethanol extract of Kepok banana leaves (Musa paradisiaca L.) at concentrations of $35 \%, 40 \%$, and $45 \%$ is not effective as an antibacterial seen from the resulting inhibition zone is very weak (less than 5).
\end{abstract}

Keywords: Antibacterial, Escherichia coli, Hand sanitizer, Musa paradisiaca L., Staphylococcus aureus

\section{PENDAHULUAN}

Tangan merupakan salah satu media pertumbuhan mikroba, tangan yang kotor menjadi sarang pertumbuhan mikroba seperti Staphylococcus aureus dan Escherichia coli ataupun bakteri lainnya. Efek yang terjadi jika tangan terkena paparan bakteri Staphylococcus aureus dan Escherichia coli dapat menyebabkan penyakit pada manusia seperti diare, berbagai infeksi seperti infeksi pada luka, infeksi folikel rambut, meningitis dan pneumonia (Supartono, 2006). Salah satu cara untuk mencegah tumbuhnya mikroba di tangan dengan cara menjaga

• email korespondensi: yaniambari87@gmail.com 
kebersihan tangan. Cara menjaga kebersihan tangan adalah dengan mencuci tangan menggunakan sabun ataupun menggunakan antiseptik (hand sanitizer). Tujuan mencuci tangan menggunakan sabun dan air mengalir lebih efektif membunuh kuman dibandingkan dengan cuci tangan hanya dengan menggunakan air saja (Purwandari et al, 2013).

Hand sanitizer merupakan salah satu bahan antiseptik berupa gel yang sering digunakan masyarakat sebagai media pencuci tangan yang praktis. Penggunaan hand sanitizer lebih efektif dan efisien bila dibanding dengan menggunakan sabun dan air sehingga masyarakat banyak yang tertarik menggunakannya. Adapun kelebihan hand sanitizer dapat membunuh kuman dalam waktu relatif cepat, karena mengandung senyawa alkohol (etanol, propanol, isopropanol) dengan konsentrasi $\pm 60 \%$ sampai $80 \%$ dan golongan fenol (klorheksidin, triklosan). Menurut hasil penelitian Rini \& Nugraheni (2018) bahwa antiseptik pada beberapa merk dengan kadar alkohol $60-70 \%$ tanpa tambahan zat antibakteri lainnya memiliki sifat yang lebih polar, sehingga diameter daya hambat yang dihasilkan lebih besar pada bakteri Staphylococcus aureus. Penggunaan alkohol secara terus menurus tidaklah baik untuk tangan sehingga peneliti mencari alternatif untuk mengurangi pengggunaan alkohol yang berasal dari bahan alam yang relatif cukup atau lebih aman bagi kulit. Salah satu bahan yang dapat digunakan sebagai antiseptik pada gel hand sanitizer adalah tanaman pisang.

Priosoeryanto, dkk (2006) melaporkan bahwa pelepah pisang mempunyai efek sebagai antibakteri karena terdapat saponin, tannin, dan flavanoid. Hal ini diperkuat dengan penelitian yang telah dilakukan oleh Nur (2012) bahwa adanya zat antibakteri yang terkandung dalam tanaman pelepah pisang ambon akan menghambat pertumbuhan atau mematikan bakteri patogen seperti Stapnhylococcus aureus, Pseudomonas aeuroginosa dan Escherichia coli. Tanaman pisang khususnya bagian pelepahnya masih sangat sedikit diteliti sebagai antibakteri dan belum dibuat sebagai sediaan (antiseptik gel hand sanitizer), oleh karena itu peneliti tertarik untuk melakukan penelitian menggunaan ekstrak pelepah tanaman pisang kepok sebagai gel hand sanitizer alami dan lebih aman. Pada penelitian ini digunakan pelepah pisang kepok karena ekstrak setiap bagian dari tanaman pisang kepok memiliki daya hambat terhadap bakteri (Ayu et al., 2013). Menurut Fadhilah (2017) cairan pelepah pisang kepok dapat mengurangi pertumbuhan bakteri dengan adanya penurunan jumlah koloni ditangan, dan menurut Wijayanti (2017) belum diketahui stabilitas cairan pelepah pisang kepok hand sanitizer sehingga disarankan untuk mengembangkan dengan mengformulasikan sebagai gel. Hayati (2010) menjelaskan bahwa sampel tanaman yang sama tetapi berasal dari daerah yang berbeda belum tentu memiliki aktivitas yang sama, yang dikarenakan jumlah senyawa aktif dapat dipengaruhi oleh beberapa faktor yaitu kondisi lingkungan disekitar, iklim, tanah, dan morfologi tanaman.

\section{METODE PENELITIAN}

Rancangan Penelitian. Jenis penelitian yang digunakan adalah penelitian eksperimental dengan menggunakan metode analisis statistik parametrik dengan menggunakan oneway ANOVA. Sedangkan untuk data yang tidak terdistribusi secara normal menggunakan analisis statistik non parametrik Kruskal Wallis untuk mengetahui perbedaan yang signifikan pada setiap formula dan Mann whitney untuk mengetahui ada atau tidaknya perbedaan hubungan antara formula.

Bahan. Bahan yang digunakan dalam penelitian ini adalah simplisia pelepah pisang kapok (Musa paradisiaca L.) yang diperoleh dan dideterminasi dari Materia Medika Malang. Ekstrak pelepah pisang kapok (Musa paradisiaca L.), Karbopol, Propilenglikol (Brataco), Gliserin (Brataco), Metil paraben (Brataco), TEA (Brataco), dan Etanol (Brataco). Skrining fitokimia menggunakan bahan $\mathrm{FeCl}_{3} 1 \%$, gelatin $10 \%$, serbuk $\mathrm{Mg}$ dan $\mathrm{HCl} 2 \mathrm{~N}$. Uji antiseptik menggunakan media Nutrien agar (NA), media Nutrien Broth (NB), media Muller Hinton Agar (MHA), aquadest steril, kertas cakram, biakan bakteri Escherichia coli dan Staphylococcus aureus.

Alat. Alat yang digunakan dalam penelitian ini adalah timbangan digital (Ohaus), beaker glass (Iwaki), gelas ukur (Iwaki), Erlenmeyer (Iwaki), alminium foil, kertas saring, tabung reaksi dan raknya, gelas arloji, gelas objek, mortir dan stemper, sudip, penangas air, batang pengaduk, dan Oven UN 30-32 liter. Alat untuk uji antiseptik meliputi cawan petri, cutton bath, plastik wrap, bunsen burner, autoklaf GEA YX-24LDJ, jarum ose, dan Laminar Air Flow (LAF).

Pembuatan Ekstrak. Ekstraksi dilakukan dengan metode maserasi atau perendaman. Serbuk 
pelepah pisang kepok ditimbang sebanyak $2 \mathrm{~kg}$ kemudian dimasukkan ke dalam wadah maserasi dan ditambah etanol 96\% sebanyak 15 liter, dimaserasi selama 5 hari dengan dilakukan pengadukan disetiap harinya. Ekstrak yang sudah disaring kemudian dipekatkan dengan menggunakan alat rotary evaporator, sehingga diperoleh ekstrak kental. Konsentrasi ekstrak yang digunakan yaitu $35 \%, 40 \%$, dan $45 \%$.

\section{Uji Skrining Fitokimia.}

\section{a. Uji Tanin dan Polifenol}

Uji Polifenol: Sampel ekstrak teh hijau diambil sebanyak $1 \mathrm{~mL}$ ditambahkan larutan $\mathrm{FeCl}_{3} \quad 10 \%$ dalam akuades. Reaksi positif jika memberikan warna hijau, merah, ungu, biru, atau hitam yang kuat (Harbone,1987). Uji Tanin: Sampel ekstrak teh hijau diambil sebanyak $1 \mathrm{~mL}$ ditetesi dengan 5 tetes $\mathrm{NaCl} 10 \%$ dan disaring. Filtrat yang diperoleh ditambah dengan gelatin $1 \%$ dan $\mathrm{NaCl}$ $10 \%$. Uji positif adanya senyawa tanin ditandai dengan adanya endapan putih (Tiwari et al., 2011).

\section{b. Uji Saponin}

Identifikasi senyawa saponin dapat dilakukan dengan Metode Forth yaitu $2 \mathrm{~mL}$ sampel dimasukkan ke dalam tabung reaksi, kemudian ditambahkan $10 \mathrm{~mL}$ aquades, lalu dikocok selama 30 detik. Apabila terbentuk busa yang mantap (tidak hilang selama 30 detik) menunjukkan adanya saponin (Hanani, 2015).

\section{c. Uji Flavonoid}

Identifikasi senyawa flavonoid dapat dilakukan dengan cara ekstrak kental dilarutkan terlebih dahulu dengan metanol. Kemudian, dimasukkan sedikit ke dalam tabung reaksi, lalu ditambahkan pita $\mathrm{Mg}$. Setelah itu, ditambahkan $\mathrm{HCl}$ pekat sebanyak $1 \mathrm{~mL}$ ke dalam tabung reaksi. Perubahan warna larutan menjadi warna kuning, jingga, merah dan hijau menandakan adanya flavonoid (Depkes RI, 1979).

\section{d. Uji Alkaloid}

Identifikasi senyawa alkaloid dapat dilakukan dengan cara Sejumlah sampel dilarutkan dalam beberapa tetes asam sulfat $2 \mathrm{~N}$ kemudian diuji dengan 2 pereaksi alkaloid yaitu pereaksi Dragendorff dan pereaksi Meyer. Hasil uji positif diperoleh bila terbentuk endapan merah jingga dengan perekasi Dragendorff dan endapan putih kekuningan dengan pereaksi Meyer (Harborne, 1987)

\section{e. Uji Steroid}

Identifikasi senyawa steroid dapat dilakukan dengan Ekstrak dilarutkan dengan 0,5 kloroform, campurkan 0,5 asam asetat anhidrat, campurkan 2 $\mathrm{ml}$ asam sulfat pekat melalui dinding tabung, terbentuknya cincin kecoklatan/ violet pada perbatasan larutan menunjukan adanya kandungan kimia triterpenoid. Jika terbentuknya cincin biru kehijauan menunjukan adanya kandungan kimia steroid (Jones and Kinghon, 2009).

\section{Rancang Formula Gel Gel Hand Sanitizer Ekstrak Etanol Pelepah Pisang Kepok.}

Rancang formulasi sediaan gel hand sanitizer dengan bahan aktif ekstrak pelepah pisang kepok (Musa paradisiaca L.) dapat dilihat pada tabel 1.

Tabel 1. Formula Gel Ekstrak Etanol Pelepah Pisang Kepok

\begin{tabular}{llccc}
\hline \multirow{2}{*}{ Bahan } & \multicolumn{1}{c}{ Fungsi } & \multicolumn{3}{c}{ Formula (\%) b/v } \\
\cline { 3 - 5 } & & F1 & F2 & F3 \\
\hline Ekstrak Pelepah Pisang & Bahan Aktif & 35 & 40 & 45 \\
Karbopol & Basis Gel & 0,5 & 0,5 & 0,5 \\
Propilenglikol & Humektan & 5 & 5 & 5 \\
Gliserin & Humektan & 10 & 10 & 10 \\
Metil paraben & Pengawet & 0,1 & 0,1 & 0,1 \\
TEA & Alkalizing Agent & 2 & 2 & 2 \\
Etanol & Kosolven & 5 & 5 & 5 \\
Aquadest & Pelarut & Ad & Ad & $\mathrm{Ad}$ \\
& & $100 \%$ & $100 \%$ & $100 \%$ \\
\hline
\end{tabular}

\section{Pembuatan Gel Hand Sanitizer Ekstrak Etanol Pelepah Pisang Kepok.}

Cara pembuatan Gel Hand Sanitizer ekstrak etanol pelepah pisang kepok (Musa paradisiaca L.) dengan basis karbopol yaitu dengan mendispersikan karbopol ke dalam aquadest panas hingga mengembang, kemudian di aduk cepat. Metil paraben dilarutkan dengan etanol hingga larut, kemudian dimasukkan dalam basis gel. Propilen glikol dan gliserin dicampur hingga homogen, kemudian ditambahkan ekstrak pelepah pisang (F1 35\%, F2 40\%, F3 45\%) diaduk hingga homogen, kemudian ditambahkan kedalam basis 
gel dan diaduk dengan konstan. Tambahkan TEA (trietanolamin) kedalam campuran sedikit demi sedikit dan diaduk hingga homogen. Sisa aquadest ditambahkan sampai volume $100 \mathrm{ml}$ sedikit demi sedikit. Sediaan gel yang didapat disimpan pada wadah yang tertutup rapat. Cara yang digunakan sama pada konsentrasi ekstrak pelepah pisang kepok.

\section{Uji Efektifitas Antiseptik Terhadap Bakteri.} Agar muller hilton yang telah cair (suhu $40^{\circ} \mathrm{C}$ ) dituangkan kedalam cawan petri steril dan dibiarkan membeku. Inokulasi bakteri Staphylococcus aureus dengan dimasukkan swab kapas ke medium tabung reaksi yang berisi biakan bakteri ke dalam medium muller hilton dan diratakan. Kemudian dicelupkan kertas cakram pada sediaan gel hand sanitizer tiap konsentrasi dan kontrol masing-masing 1 kertas cakram dalam waktu tertentu. Kontrol positif digunakan bahan aktif gel hand sanitizer yang ada dipasaran yaitu alkohol $70 \%$ dan kontrol negatif yaitu aquadest. Setelah itu diletakkan kertas cakram diatas agar yang membeku secara aseptik. Sebelum itu media agar dibagi dalam 3 wilayah untuk masing-masing konsetrasi sediaan gel hand sanitizer dengan cara memberi tanda pada bagian bawah cawan petri. Setelah itu inkubasi cawan petri pada suhu $36^{\circ} \mathrm{C}$ selama 24 jam. Zona hambat diukur disekitar kertas cakram untuk tiap kontrol setelah diinkubasi selama 24 jam. Untuk ini dilakukan sebanyak 5 kali replikasi. Begitu juga perlakuan terhadap bakteri Escherichia coli.

\section{HASIL DAN PEMBAHASAN}

Proses ekstraksi yang digunakan pada penelitian ini adalah maserasi yang dikarenakan metode tersebut paling banyak digunakan, cara pengerjaan dan alat yang digunakan mudah dilakukan dan sederhana (Agoes, 2007). Keunggulan dari metode ini yaitu tidak membutuhkan pelarut yang banyak dan penggunaan alatnya sederhana. Pelarut yang digunakan untuk ekstraksi yaitu etanol $96 \%$ yang memiliki keuntungan dapat melarutkan semua zat (polar dan non polar) dan selektif menarik senyawa aktif yang ada di sampel (Ditjen Pom, 2000). Hasil ekstraksi dari $2 \mathrm{~kg}$ simplisia pelepah pisang kepok didapatkan ekstrak kental sebesar 83,1 gram dengan persen rendemen yaitu $0,4145 \%$ bewarna hijau dan berbau khas aromatis, kemudian dilakukan skrinning fitokimia. Hasil skrining fitokimia menunjukkan reaksi yang positif terhadap uji alkaloid, flavonoid, tannin, saponin, dan steroid. Hasil skrining fitokimia dapat dilihat pada tabel 2.

Tabel 2. Hasil Skrining Fitokimia Ekstrak Etanol Pelepah Pisang Kepok

\begin{tabular}{|c|c|c|c|}
\hline No & Uji Skrining Fitokimia & Hasil & Penjelasan \\
\hline 1. & Alkaloid & + & $\begin{array}{l}\text { Terbentuk endapan putih dan ekstrak berwarna jingga pada } \\
\text { penambahan reagen meyer dan dragendroff, menunjukkan } \\
\text { sampel positif alkaloid. }\end{array}$ \\
\hline 2. & Flavonoid & + & $\begin{array}{l}\text { Pada penambahan } \mathrm{HCl} \text { pekat } 1 \mathrm{ml} \text { berubah menjadi warna } \\
\text { jingga, menunjukkan sampel positif flavonoid jenis flavon, dan } \\
\text { pada penambahan } \mathrm{Zn} \text { dan } \mathrm{HCl} \text { pekat } 1 \mathrm{ml} \text { berubah warna } \\
\text { menjadi hijau dan ada endapan warna abu-abu, menunjukkan } \\
\text { sampel positif flavonoid. }\end{array}$ \\
\hline 3. & Tannin & + & $\begin{array}{l}\text { Pada penambahan gelatin terbentuk endapan putih, } \\
\text { menunjukkan positif tannin, dan pada penambahan Fecl } 1 \% \\
\text { berubah warna menjadi kehitaman, menunjukkan positif } \\
\text { tannin. }\end{array}$ \\
\hline 4. & Saponin & + & $\begin{array}{l}\text { Terbentuk busa mantap ( } 30 \text { detik tidak hilang) pada saat } \\
\text { dikocok dan berwarna hijau kekuningan, menunjukkan positif } \\
\text { saponin. }\end{array}$ \\
\hline 5. & Steroid dan terpenoid & + & $\begin{array}{l}\text { Terbentuk warna merah pada penambahan asam asetat } \\
\text { anhidrat dan asam sulfat pekat, menunjukkan adanya } \\
\text { kandungan kimia triterpenoid. }\end{array}$ \\
\hline
\end{tabular}

Penelitian efektifitas gel hand sanitizer ini menggunakan pelepah pisang kepok sebagai bahan aktif karena memiliki efek sebagai antibakteri berdasarkan penelitian dari Nur (2012) karena terdapat saponin yang berfungsi sebagai antiseptik sehingga dapat digunakan sebagai antibakteri dengan cara merusak permeabelitas protein, tannin yang berfungsi sebagai penghambat tumbuhnya bakteri dengan memunculkan denaturasi protein dan mengganggu 
reaksi enzimatis pada bakteri (Palczar, J.M et al, 1988) dan flavonoid berfungsi untuk menghambat pertumbuhan bakteri dengan cara menghambat metabolisme energi (Herry, 2013). Penggunaan pelepah sendiri untuk melestarikan dan memanfaatkan limbah pelepah tanaman pisang yang biasanya tidak dimanfaatkan dan memanfaatkankannya sebagai antibakteri berdasarkan senyawa metabolit sekunder yang ada ditanaman tersebut. Pemeriksaan fitokimia pada ekstrak etanol pelepah pisang kepok menunjukkan hasil yang positif mengandung alkaloid yang berfungsi sebagai antibakteri dengan cara mengganggu komponen penyusunnya sehingga menyebabkan kematian (Darsana, et all, 2012), flavonoid, steroid atau terpenoid dapat digunakan sebagai anti inflamasi dengan cara merubah membran sel menjadi rapuh (Ahmed, 2007) tannin, dan saponin.

Gel hand sanitizer ekstrak etanol pelepah pisang kepok menggunakan formulasi termodifikasi standart gel pada umumnya dengan menggunakan basis karbopol, pemilihan basis karbopol dikarenakan karbopol banyak digunakan dalam sediaan farmasi dalam bentuk cairan maupun setengah padat. Karbopol dengan konsentrasi $0,5 \%$ digunakan sebagai basis gel, dikarenakan dapat mengembang dan stabil dalam air, gliserin dan menghasilkan massa gel yang transparan, dan konsentrasi tersebut baik jika digunakan untuk gelling agent (Astuti, 2015).
Bahan tambahan yang digunakan yaitu propilen glikol dengan konsentrasi 5\%, gliserin 10\% karena formulasi standart basic gel menggunakan konsentrasi tersebut, dan pada konsentrasi tersebut sering digunakan sebagai humektan, metil paraben sering digunakan sebagai pengawet untuk kosmetik dan makan, pada formulasi ini menggunakan konsentrasi $0,1 \%$ digunakan sebagai pengawet dan ditambahkan etanol sebagai kosolven (melarutkan metil paraben), metil paraben berfungsi sebagai pengawet dikarenakan untuk sediaan gel mempunyai kandungan air yang tinggi sehingga dapat menyebabkan terjadinya kontaminasi terhadap mikroba (Arikumalasari, et $a l, 2010)$, penambahan TEA dengan konsentrasi $2 \%$ bertujuan untuk menjaga $\mathrm{pH}$ sediaan tetap stabil.

\section{Uji Efektifitas}

Uji efektifitas bertujuan untuk mengetahui kemampuan sediaan untuk menghambat bakteri dengan melihat zona hambat yang dihasilkan. Menurut David dan Stout (1971) diameter zona hambat lebih dari $20 \mathrm{~mm}$ responnya sangat kuat, 10 sampai $20 \mathrm{~mm}$ responnya kuat, diameter zona hambat 5 sampai 10 responnya sedang, dan diameter zona hambat kurang dari 5 responnya lemah. Hasil uji efektifitas sediaan gel hand sanitizer ekstrak etanol pelepah pisang kepok dapat dilihat pada tabel $\mathbf{3}$ dan tabel $\mathbf{4}$ di bawah ini.

Tabel 3. Uji Efektifitas Sediaan Gel Hand Sanitizer Ekstrak Pelepah Pisang Kepok (Musa paradisiaca L.) Terhadap Bakteri S. aureus

\begin{tabular}{cccccc}
\hline Pengulangan & $\begin{array}{c}\text { Kontrol Negatif } \\
(\mathbf{m m})\end{array}$ & $\begin{array}{c}\text { Kontrol Positif } \\
(\mathbf{m m})\end{array}$ & \multicolumn{3}{c}{ Zona Hambat (mm) } \\
\cline { 2 - 6 } & & Staphylococcus aureus & & F1 & F3 \\
\hline $\mathbf{1}$ & 0 & 9,15 & 0 & 2,875 & 3,25 \\
$\mathbf{2}$ & 0 & 9,15 & 1 & 2,875 & 3,25 \\
$\mathbf{3}$ & 0 & 6,5 & 0,5 & 0,875 & 2,625 \\
$\mathbf{4}$ & 0 & 9,125 & 1 & 1,875 & 2,125 \\
$\mathbf{5}$ & 0 & 8,25 & 1,375 & 1,625 & 2 \\
$\mathbf{6}$ & 0 & 9,5 & 0 & 1,75 & 2,25 \\
Jumlah & 0 & 51,675 & 3,875 & 11,875 & 15,5 \\
\hline Rata-rata & $\mathbf{0}$ & $\mathbf{8 , 6 1 2 5}$ & $\mathbf{0 , 6 4 5 3}$ & $\mathbf{1 , 9 7 9}$ & $\mathbf{2 , 5 8 3}$ \\
\hline
\end{tabular}




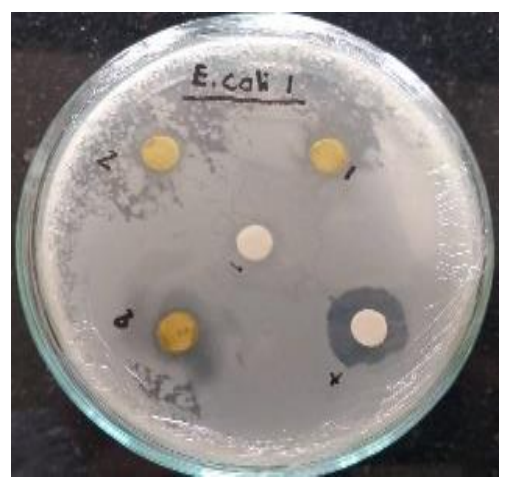

Gambar 1. Zona Hambat terhadap

Bakteri Escherichia coli

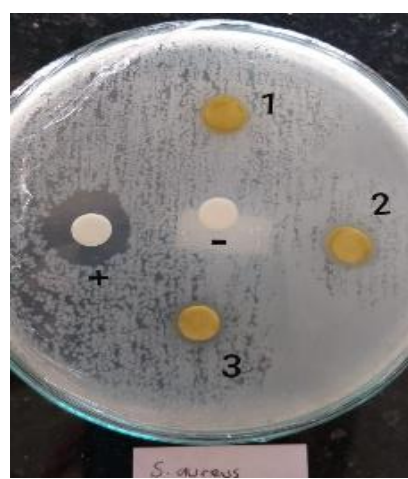

Gambar 2. Zona Hambat terhadap

Bakteri Staphylococcus aureus

\section{Keterangan $+=$ Kontrol Positif Alkohol 70\%}

- = Kontrol Negatif Aquadest

1 = Formulasi 1 Konsentrasi Ekstrak 35\%

2 = Formulasi 2 Konsentrasi Ekstrak 40\%

3 = Formulasi 3 Konsentrasi Ekstrak 45\%

Tabel 4. Uji Efektifitas Sediaan Gel Hand Sanitizer Ekstrak Pelepah Pisang Kepok (Musa paradisiaca L.) Terhadap Bakteri Escherichia coli

\begin{tabular}{|c|c|c|c|c|c|}
\hline \multirow[t]{2}{*}{ Pengulangan } & \multirow{2}{*}{$\begin{array}{c}\text { Kontrol Negatif } \\
(\mathrm{mm})\end{array}$} & \multirow{2}{*}{$\begin{array}{c}\text { Kontrol Positif } \\
(\mathbf{m m})\end{array}$} & \multicolumn{3}{|c|}{ Zona Hambat (mm) } \\
\hline & & & F1 & F2 & F3 \\
\hline \multicolumn{6}{|c|}{ Escherichia coli } \\
\hline 1 & 0 & 10,3 & 0 & 0 & 2,625 \\
\hline 2 & 0 & 9,75 & 0 & 0 & 3,75 \\
\hline 3 & 0 & 10,3 & 0 & 1 & 1,375 \\
\hline 4 & 0 & 7,375 & 0 & 0 & 1,5 \\
\hline 5 & 0 & 6,5 & 0 & 0 & 0,25 \\
\hline 6 & 0 & 5,5 & 0 & 0 & 1,75 \\
\hline Jumlah & 0 & 49,725 & 0 & 0 & 11,25 \\
\hline Rata-rata & $\mathbf{0}$ & 8,2875 & $\mathbf{0}$ & $\mathbf{0}$ & 1,875 \\
\hline
\end{tabular}

Hasil uji normalitas pada uji efektifitas Uji Efektifitas Sediaan Gel Hand Sanitizer Ekstrak Pelepah Pisang Kepok (Musa paradisiaca L.) Terhadap Bakteri Escherichia coli dan Stapnhylococcus aureus menggunakan analisis Shapiro Wilk (SPSS 20) menunjukkan bahwa distribusi data tidak normal, sehingga dilanjutkan dengan uji non parametrik menggunakan uji Kruskal Wallis untuk mengetahui perbedaan yang signifikan pada setiap formula hasil dapat dilihat pada tabel 5 dan Mann Whitney untuk mengetahui ada atau tidaknya perbedaan hubungan antara formula hasil dapat dilihat pada table $\mathbf{6}$ dan tabel 7

Tabel 5. Uji Kruskal Wallis Sediaan Gel Hand Sanitizer Ekstrak Pelepah Pisang Kepok

\begin{tabular}{ccc}
\hline Jenis Bakteri & Signifikan & Asymp. Sig \\
\hline $\begin{array}{c}\text { Staphylococcus aureus } \\
\text { Escherichia coli }\end{array}$ & \multirow{2}{*}{0,05} & 0,000 \\
& & 0,000 \\
\hline
\end{tabular}

Hasil uji Kruskal Wallis pada bakteri Staphylococcus aureus dan Escherichia coli didapatkan nilai Asymp. Sig dengan nilai yang sama yaitu 0,000 dimana nilai signifikan kurang dari 0,05 dimana tiap formulasi mempunyai perbedaan secara nyata, kemudian dilanjutkan uji Mann Whitney untuk mengetahui ada atau tidaknya perbedaan hubungan antara formula dan kontrol. 
Tabel 6. Uji Mann Whitney Sediaan Gel Hand Sanitizer Ekstrak Pelepah Pisang Kepok Terhadap Bakteri Staphylococcus aureus

\begin{tabular}{cccc}
\hline Perlakuan & $\begin{array}{c}\text { Signifikan } \\
\text { (p-value) }\end{array}$ & Keterangan \\
\hline \multirow{2}{*}{ Kontrol - } & F1 35\% & 0,002 & Ada perbedaan \\
& F2 $40 \%$ & 0,022 & Ada perbedaan \\
& F3 45\% & 0,002 & Ada perbedaan \\
Kontrol - & 0,002 & Ada perbedaan \\
& F1 35\% & 0,002 & Ada perbedaan \\
& F2 40\% & 0,004 & Ada perbedaan \\
F1 35\% & F3 45\% & 0,004 & Ada perbedaan \\
& Kontrol - & 0,022 & Ada perbedaan \\
& Kontrol + & 0,004 & Ada perbedaan \\
& F2 40\% & 0,016 & Ada perbedaan \\
& F3 45\% & 0,004 & Ada perbedaan \\
F2 40\% & Kontrol - & 0,002 & Ada perbedaan \\
& Kontrol + & 0,004 & Ada perbedaan \\
& F1 35\% & 0,016 & Ada perbedaan \\
& F3 45\% & 0,107 & Ada perbedaan \\
& Kontrol - & 0,002 & Tidak ada perbedaan \\
& Kontrol + & 0,004 & Ada perbedaan \\
& F1 35\% $45 \%$ & 0,004 & Ada perbedaan \\
& F2 40\% & 0,107 & Ada perbedaan \\
& & & Tidak ada perbedaan \\
\hline
\end{tabular}

Tabel 7. Uji Mann Whitney Sediaan Gel Hand Sanitizer Ekstrak Pelepah Pisang Kepok Terhadap Bakteri Escherichia coli

\begin{tabular}{cccc}
\hline \multicolumn{2}{c}{ Perlakuan } & $\begin{array}{c}\text { Signifikan } \\
\text { (p-value) }\end{array}$ & Keterangan \\
\hline & Kontrol + & 0,002 & Ada perbedaan \\
Kontrol - & F1 35\% & 1,000 & Tidak ada perbedaan \\
& F2 40\% & 0,317 & Tidak ada perbedaan \\
& F3 45\% & 0,002 & Ada perbedaan \\
& Kontrol - & 0,002 & Ada perbedaan \\
Kontrol + & F1 35\% & 0,002 & Ada perbedaan \\
& F2 40\% & 0,003 & Ada perbedaan \\
& F3 45\% & 0,004 & Ada perbedaan \\
& Kontrol - & 1,000 & Tidak ada perbedaan \\
F1 35\% & Kontrol + & 0,002 & Ada perbedaan \\
& F2 40\% & 0,317 & Tidak ada perbedaan \\
& F3 45\% & 0,002 & Ada perbedaan \\
& Kontrol - & 0,317 & Tidak ada perbedaan \\
F2 40\% & Kontrol + & 0,003 & Ada perbedaan \\
& F1 35\% & 0,317 & Tidak ada perbedaan \\
& F3 45\% & 0,005 & Ada perbedaan \\
& Kontrol - & 0,002 & Ada perbedaan \\
F3 45\% & Kontrol + & 0,004 & Ada perbedaan \\
& F1 35\% & 0,002 & Ada perbedaan \\
& F2 40\% & 0,005 & Ada perbedaan \\
\hline
\end{tabular}

Ketiga formulasi gel Hand Sanitizer menunjukkan hasil yang tidak efektif sebagai antibakteri, dilihat dari zona hambat yang dihasilkan kurang dari 5 yang artinya lemah sebagai antibakteri (David dan Stout, 1971). Pengukuran diameter zona hambat dilakukan dengan cara mengukur zona hambat yang dihasilkan dikurangi dengan diameter kertas cakram. Kecilnya zona hambat yang dihasilkan dapat disebabkan oleh beberapa faktor seperti konsentrasi zat bakteri, jumlah bakteri pada medium agar, dan keadaan bakteri ( Fardiaz, 1989) konsentrasi ekstrak yang diberikan, senyawa aktif yang ada di pelepah pisang kepok sedikit (alkaloid, flavonoid, tannin, saponin, dan steroid) 
sehingga tidak dapat menembus dinding sel bakteri dan pengaruh lingkungan dan kondisi tanah dapat mempengaruhi zat yang ada di tanaman (Sinaga, 2007), Menurut Hayati (2010) sampel tanaman yang sama namun berasal dari daerah atau tempat tertentu belum tentu mempunyai aktivitas yang sama pula, serta ketelitian dan sterilisasi alat yang digunakan juga dapat mempengaruhi hasil yang didapatkan.

\section{SIMPULAN}

Berdasarkan hasil penelitian yang telah dilakukan bahwa sediaan gel hand sanitizer ekstrak etanol pelepah pisang kepok (Musa paradisiaca L.) terhadap bakteri Staphuylococcus aureus pada konsentrasi 35\% didapatkan zona hambat sebesar 0,6453 mm, konsentrasi $40 \%$ didapatkan zona hambat sebesar $1,979 \mathrm{~mm}$, dan konsentrasi $45 \%$ didapatkan zona hambat sebesar 2,583 mm sedangkan untuk bakteri Eschericihia coli pada konsentrasi ekstrak 35\% dan $40 \%$ didapatkan zona hambat sebesar $0 \mathrm{~mm}$, dan $45 \%$ didapatkan zona hambat sebesar $1,875 \mathrm{~mm}$ dimana bisa dikatakan bahwa gel gel hand sanitizer ekstrak etanol pelepah pisang kepok (Musa paradisiaca L.) tidak efektif sebagai antibakteri Eschericihia coli dan Staphuylococcus aureus dilihat dari zona hambat yang dihasilkan sangat lemah (kurang dari $5 \mathrm{~mm}$ )

\section{DAFTAR PUSTAKA}

Ahmed, Bahar. 2007. Chemichal of Natural Product. New Delhi: Departement of Pharmacheutical Chemistry Faculty of Science Jamia Hamdard.

Astuti, I.Y., Hartati, D. dan Aminiati, A. 2010. Peningkatan Aktivitas Antijamur Candida albicans Salep Minyak aaatsiri Daun Sirih (Piper bettle LINN.) melalui Pembentukan Kompleks Inklusi dengan $\beta$-sikloodekstrin. Majalah Obat Tradisional 15: 94-99.

Ayu P. Ningsih, Nurmiati, A. Agustin. Uji Aktivitas Antibakteri Ekstrak Kental Tanaman Pisang Kepok Kuning (Musa paradisiaca Linn.) terhadap Staphylococcus aureus dan Escherichia coli. J. Bio. UA. 2013. 2 (3); 207 -213
Brooks, G.F., J.S. Butel, dan S. A., Morse. 2005. Mikrobiologi Kedokteran. Salemba Medika. Jakarta.

Darsana, I.G.O., I.N.K. Besung dan H. Mahatmi. 2012. Potensi Daun Binahong (Anredera cordifolia (Tenore) Steenis) dalam Menghambat Pertumbuhan Bakteri Escherichia coli secara In Vitro. Indonesia Medicus Veterinus, 1 (3): 337-351.

Davis, W. W. dan T. R. Stout. 1971. Disc Plate Methods of Microbiological Antibiotic Assay. Applied Microbiology 22 (4): 666670

Departemen Kesehatan Republik Indonesia. 1995. Materia Medika Indonesia. Jilid IV. Jakarta: Direktorat Jendral Pengawasan Obat dan Makanan.

Depkes RI. 1979. Farmakope Indonesia, Edisi Ketiga, Departemen Kesehatan Republik Indonesia, Jakarta.

Ditjen POM. Farmakope Indonesia. 1995. Edisi IV. Departemen Kesehatan Republik Indonesia. Jakarta.

Fadhilah, N. 2017. Potensi Pelepah Daun Pisang Kepok Sebagai Hand Sanitizer Alam. SKRIPSI.FKIP UMS.

Ferdiaz, A. 1989. Analisa Mikribiologi Pangan. Raja Grafindo Persada. Jakarta.

Garg, A., Aggarwal, D., et al. 2002. Spreading of Semisolid Formulation: An Update. Pharmaceutical Technology. Halaman 84105.

Hanani, M. S. E. 2015. Analisis Fitokimia. Jakarta: Penerbit Buku Kedokteran EGC.

Harborne, J., B. 1987. Metode Fitokimia. Penentuan Cara Modern Menganalisa Tumbuhan. Bandung: Penerbit ITB.

Hayati, E. 2010. Pengaruh Pupuk Organik dan Anorganik Terhadap Kandungan Logam Berat Dalam Tanah dan Jaringan Tanaman Selada. Fakultas Pertanian. Universitas Syiah Kuala. 5: 113 - 123. 
ICH. 1996. Stability Testing: Photostabilty Testing of New Drug Substance and Product Q1b. ICH Harmonised Tripartite Guidline.

Jones, W.P. and A. D. Kinghorn. 2006. Extraction of plant secondary metabolites. In: Sarker, S.D., Latif, Z. And Gray, A. I. Eds Natural produxts isolation. 2nd Ed. New Jersey. Human Press.

Konstantianus, M.D.N., Supartono., dan Harjono. 2016. Isolasi Senyawa Bioaktif Batang Pisang Ambon (Musa paradisiaca Var. Sapientum) Sebagai Bahan Baku Antibakteri. Ind0. J. Chem. Sci. 5 (3).

Kori Yati., Mahdi Jufri., et al. 2018. Pengaruh Variasi Konsentrasi Hidroxy Propyl Methy Cellulose (HPMC) Terhadap Stabilitas Fisik Gel Ekstrak Tembakau (Nicotiana tabaccum L.) dan Aktifitasnya Terhadap Streptococcus mutans.

Mappa T, Edy HJ, dan Kojong. 2013. Formulasi Gel Ekstrak Daun Sasaladahan (Peperomia pellucida (L.) H.B.K) dan Uji Efektifitasnya Terhadap Luka Bakar Pada Kelinci (Orytolagus cuniculuc). Jurnal Ilmiah Farmasi 2 (2): 49 - 55. Market Scope and Opportunities. International Journal of Phama and Bio Sciences. 1 (2): $1-21$.

Naibaho, Olivia H. Paulina V.Y. Yamlean, Weny Wiyono. 2013. Pengaruh Basis Salep Terhadap Formulasi Sediaan Salep Ekstrak Daun Kemangi (Ocimun Sanctum L.) Pada Kulit Punggung Kelinci Yang Dibuat Infeksi Staphyloccocus Aureus., Jurnal Ilmiah Farmasi., UNSRAT. Vol 2 N0 02. ISSN 2302-2493.

Jumriah, N. Dwyana, Z., et al. 2012. Bioaktivitas Pelepah Pisang Ambon Musa paradisiaca var. sapientum Terhadap Pertumbuhan Bakteri Staphylococcus aureus, Pseudomonas aeuroginosa dan Escherichia coli. Tersedia: http://repository.unhas.ac.id/bitstream/ha ndle/123456789/4226/

JURNAL\%20JUMRIAH\%20NUR.pdf?s equence $=1$ [15 Februari 2015]
Pelczar, M. J., dan Chan, E. S. 1988. Dasar-dasar Mikrobiologi 2. Jakarta: UI Press.

Purwandari, R., Ardiana A., Wantiyah. 2013. Hubungan antara perilaku mencuci tangan dengan insiden diare pada anak usia sekolah di kabupaten jember. Jurnal Keperawatan. 4(2): 122 - 130

Priosoeryanto, B. P., H. Huminto., I. Wientarsih dan S. Estuningsih. 2006. Aktifitas Getah Batang Pohon Pisang Dalam Proses Persembuhan Luka Dan Efek Kosmetiknya Pada Hewan. http://repository.ipb.ac.id. 25 Agustus 2011.

Rahmawati, D., Sukmawati, A. dan Indrayudha, P. 2010. Formulasi Krim Minyak Atsiri Rimpang Temu Giring (Curcuma heyneana Val \& Zijp): Uji Sifat Fisik dan Daya Antijamur Terhadap Candida albicans Secara In Vitro, Majalah Obat Tradisional, 15 (2), 56-63.

Rini, E. P., \& Nugraheni E. R. 2018. Uji Daya Hambat Berbagai Merek Handsanitizer Gel Terhadap Pertumbuhan Bakteri Escherichia coli dan Staphylococcus aureus. Journal of Pharmaceutical Science and Clinical Research, 1 (10), 18-26.

Rumaisya, A dan Anif N. A. 2019. Uji Aktivitas Ekstrak Dan Getah Pelepah Serta Bonggol Pisang Kepok Kuning (Musa paradisiaca Linn.) Terhadap Bakteri Pseudomonas aeruginosa dan Klebsiella pneumoniae Dengan Metode Difusi Agar. Journal of Pharmaceutical Science and Clinical Research, 01 (29-38).

Sinaga, R. 2007. Analisis Model Ketahanan Rumput Gajah dan Rumput Raja Akibat Cekaman Kekeringan Berdasarkan Respons Anatomi Akar dan Daun. Jurnal Biologi Sumatra. 2 (1): 17-2-0.

Supartono. 2006. Pemeriksaan Staphylococcus aureus Pada Organ Dalam Hewan dan Bahan Makanan. Pusat Penelitian dan Pengembangan Peternakan. Diakses tanggal 10 Februari 2017. 
Tiwari, P., Kumar, B., Kaur, M., Kaur, G. \& Kaur, H. (2011). A review: Phytochemical screening and extraction. Internationale Pharmaceutica Sciencia. 1(1): 98-106.

Ulaen, Selfie P.J., Banne, Yos Suatan \& Ririn A. 2012. Pembuatan Salep Anti Jerawat dari
Ekstrak Rimpang Temulawak (Curcuma xanthorrhiza Roxb.). Jurnal Ilmiah Farmasi. 3 (2), 45-49.

Wijayanti, M. 2017. Stabilitas Hand Sanitizer Berbahan Dasar Bonggol dan Pelepah Pisang Kepok. SKRIPSI. FKIP UMS. 